Paper in International Seminar on Achieving resilience agriculture to climate change trough the development of climate based management, PERHIMPI, 17-19 Nov 2009, Bogor

\title{
ATMOSPHERIC CARBON DIOXIDE SEQUESTRATION TROUGH KARST DENUDATION PROCESS Preliminary Estimation from Gunung Sewu Karst
}

\author{
Eko Haryono, Tjahyo Nugroho Adji, M. Widyastuti, Sutanto Trijuni \\ Karst Research Group, Fac. of Geography, GMU. e.haryono@geo.ugm.ac.id; adji@geo.ugm.ac.id
}

\begin{abstract}
Karst ecosystem is known as one of the major terrestrial carbon sinks on the earth. It owes its important not only because it stores carbon binding rocks but also because karstification itself is a carbon dioxide sequestration process. The paper documented here is an estimation of carbon dioxide sequestration under karst denudation process. Denudation rate was acquired from previous works suggesting that denudation rate of Gunung Sewu Karst is $50.91 \mathrm{~m}^{3} /$ year $/ \mathrm{km}^{2}$. Taking account the area of Gunung Sewu Karst as $1300 \mathrm{~km}^{2}$, total calcium carbonate removed from the area is 165.464 ton/year. Every tonne of limestone dissolved, 0.12 ton of atmospheric carbon is absorbed. In total, Gunung Sewu Karst up takes 19,855.68 ton carbon per year or equivalent to 72.804 .16 ton/year atmospheric carbon dioxide. This figure is only from denudation process. Considering carbon sequestration through biomass production through agricultural practices, Gunung Sewu Karst ecosystem and other karst areas of Indonesia accordingly owes considerable role in climate change mitigation.
\end{abstract}

Keywords : Gunung Sewu Karst, Carbon Sequestration, Karst Denudation

\section{A. Introduction}

$\mathrm{CO}_{2}$ is one of the important green house gases of which has big contribution to global warming. In recent decades, emissions of $\mathrm{CO}_{2}$ have continued to increase (Dawson and Spannagle, 2009; Mackenzie, 2004; Parry et.al., 2007).. The increase is mainly caused by fossil fuel and land use changes. Global annual fossil $\mathrm{CO}_{2}$ emissions increased from an average of $6.4 \pm 0.4 \mathrm{GtC} / \mathrm{yr}$ in the $1990 \mathrm{~s}$ to $7.2 \pm 0.3 \mathrm{GtC} / \mathrm{yr}$ in the period 2000 to 2005. Estimated $\mathrm{CO}_{2}$ emissions associated with land use change, averaged over the $1990 \mathrm{~s}$, were 0.5 to $2.7 \mathrm{GtC} / \mathrm{yr}$, with a central estimate of $1.6 \mathrm{Gt} / \mathrm{yr}$ (Parry et.al., 2007).

Terrestrial and oceanic carbon sequestration potentials therefore are needed, to counter balance the increase of $\mathrm{CO}_{2}$ emission. Karst ecosystem is one of the carbon sink potentials. Karst landscape systems, composed primarily of limestone and dolomite, cover some $12 \%$ of the earth's land surface, and weathering of these rocks on the continents has been recognized as a sink term for atmospheric $\mathrm{CO}_{2}$. (Ford and Williams, 2007; Gornitz, 2008). It owes its important not only because it stores carbon binding rocks but also because karstification itself is a carbon dioxide sequestration process.

Karst processes are part of the world carbon, water and calcium cycles that occur at the interfaces between lithosphere, hydrosphere, atmosphere and biosphere. The $\mathrm{CO}_{2}-\mathrm{H}_{2} \mathrm{O}-\mathrm{CaCO}_{3}$ reaction is kwon as karst dynamic system which is useful in explaining the important of karst in carbon cycle (Daoxian, 2002; Grove, 2001; Liu and 
Zhao, 2000). Karst study has an important role in understanding the global carbon cycle, and thereby can contribute more to an understanding of global climate change.

The important of karst denudation in term of climate changes lies on the ability of karst ecosystem in regulating atmospheric carbon. Karst denudation consumes $\mathrm{CO}_{2}$ either from atmosphere and soils. Thereafter this paper is intended to describe the karst denudation related to $\mathrm{CO}_{2}$ sequestration and applying the concept to calculate carbon gain in Karst Gunung Sewu through karst denudation process. Calculation was based on previous works.

\section{B. The Setting of Gunug Sewu Karst}

Gunung Sewu karst is situated in three provinces, i.e. Yogyakarta, Central Java, and East Java Province, stretching $85 \mathrm{~km}$ west-east from Parangtritis Beach of Yogyakarta Special Province to Teleng Ria Beach of Pacitan-East Java. Its north-south width varies between 10 and $29 \mathrm{kms}$ with approximate area of $1300 \mathrm{~km}^{2}$. The Gunung Sewu karst is adjacent to the Indian Ocean on the south central coast of Java (Figure 1). Elevation range is between zero and $512.5 \mathrm{~m}$ above mean sea level, and the highest portions centrally located about $25 \mathrm{~km}$ from the cost line.

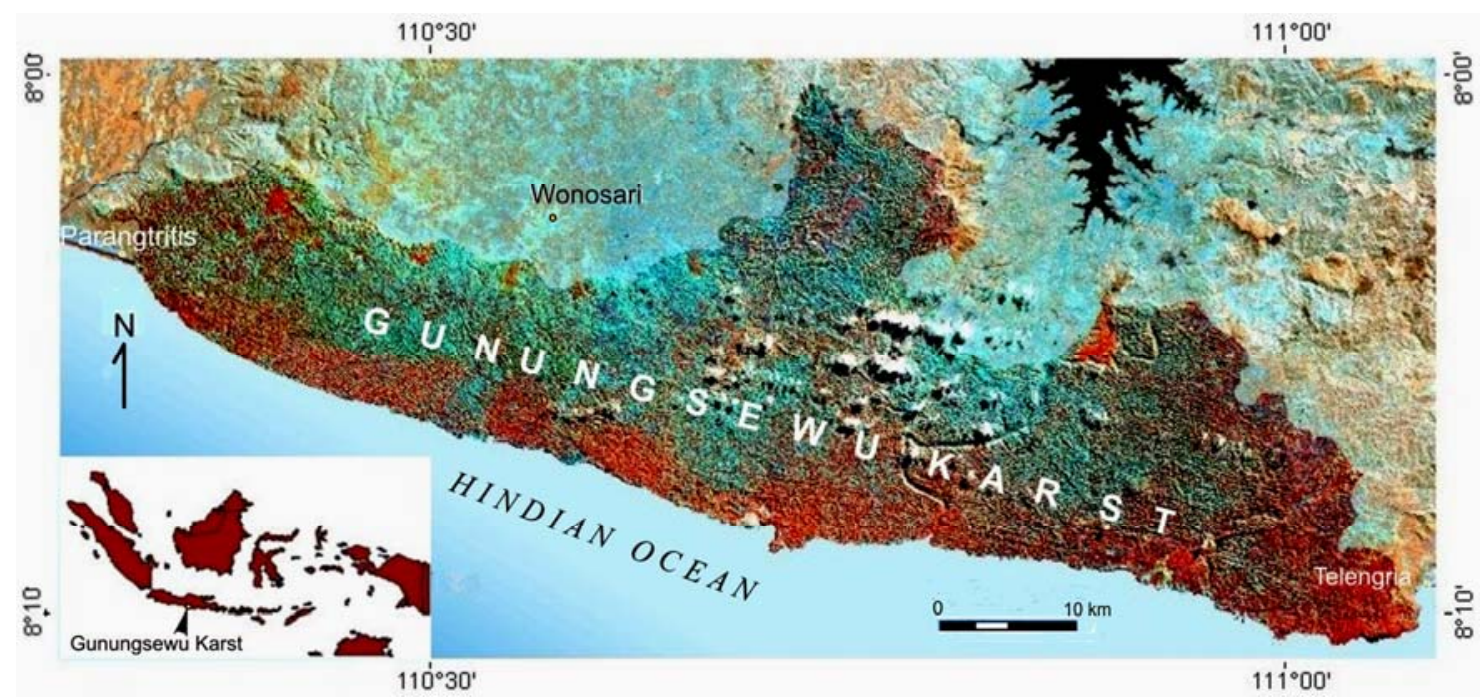

Figure 1. Landsat ETM depicting Gunung Sewu Karst and the surrounding areas

The prevailing contemporary climate in the Gunung Sewu karst is strongly influenced by the Northwest and Southeast monsoons, which produce a distinct wet season from October to April and a dry season, which may be extremely arid, between May and September. The annual rainfall, recorded from 14 local rain gauge stations between 1960 and 1997 varies between $1500 \mathrm{~mm}$ and $2986 \mathrm{~mm}$ annually. Mean annual temperature is about $27^{\circ} \mathrm{C}$ (Haryono and Day, 2004). The Gunung Sewu karst is made up of Neogen (Middle Miocene and Upper Pliocene) limestone the so-called WonosariPunung Formation. The limestone is composed of massive coral limestone in the south and bedded chalky limestone in the north (Balazs 1968; van Bemmelen 1970; Waltham et al. 1983; Surono et al. 1992; Rahadjo et al., 1995). Total thickness of the limestone exceeds $650 \mathrm{~m}$. The coral reef limestone is lithologically highly variable, but 
dominated by rudstones, packstones, and framestones. Biohermal structures are identifiable, and lenses of volcanic ash are interspersed among the carbonates (Waltham et al. 1983). The bedded, chalky limestone become more prominent towards the north and northeast, and dominates the Wonosari Plateau.

The entire karst area of Gunung Sewu is cultivated. Limited land in the area has made farmers to plant any crops in any plot of land. Even farmers extend their cultivated land up to the hill tops. To cope with shallow soils or bedrock, farmers trap the sediments/soils transported by runoff during rainy season by establishing terraces on the hill slopes, therefore farmer get more areas of soil covered land. Crops in this case are grown in the soil that is already trapped in terraces. Terraces are constructed by piling up limestone boulders crashed from karren (Haryono, 2005).

Crop productivity, not to mention, is low. Productivity of some crops grown in Gunung Sewu karst is presented in Table 1. Two cope with this situation, multiple seasonal cropping and multiple perennial crop utilization types are employed. Long adaptation has brought about this land utilization types (Haryono, 2005).

Table 1. Productivity of crops grown in Gunung Sewu Karst, sampled from karst area of Paranggupito District (in quintals/hectare)

\begin{tabular}{|l|c|l|c|}
\hline Seasonal Crops & Productivity & Perennial Crops & Productivity \\
\hline Rain-fed rice & 59.4 & Coconut & 55.0 \\
\hline Maize & 144.0 & Clove & 2.0 \\
\hline Cassava & 477.1 & Cashew nut & 6.23 \\
\hline Ground nut & 16.1 & Gnetum gnemon & 10.9 \\
\hline Soybean & 223 & Coffee & 3.1 \\
\hline
\end{tabular}

From: Office of Agricultural Affair of Winger Regency, 2004

\section{Karst Denudation and Carbon Sequestration}

\section{General Concepts}

Karst is the term used to describe a special style of landscape containing caves and extensive underground water systems that is developed on especially soluble rocks. (Ford and Williams, 2007). A soluble rock is the first prerequisite for the development of karst. It includes limestone, dolomite, marble, halite, and gypsum (Ford and William, 2007; Palmer, 2007; White 2008). However in the case Indonesia, the greatest portion of soluble rock is limestone and just a small percentage is dolomite.

Since karst areas develop under soluble rock environments, the major denudation process in the area is dissolution. Dissolution is of paramount importance in developing karst compared with its relatively minor role in other lithologies. The dissolution is incorporated by the absorption of atmosphere carbon dioxide. Atmosphere $\mathrm{CO}_{2}$ along with rain enters the karst system acting as dissolve agent and generating denudation processes. Carbon dioxide is the most soluble of the standard atmospheric gases, e.g. 64 times more soluble than $\mathrm{N}_{2}$. The dissolution process is started through reaction between water and $\mathrm{CO}_{2}$ in the form of $\mathrm{H}_{2} \mathrm{CO}_{3} \cdot \mathrm{H}_{2} \mathrm{CO}_{3}$ is unstable and breaks down in $\mathrm{H}^{+}$and $\mathrm{HCO}_{3}{ }^{-} . \mathrm{H}^{+}$ion then replaces $\mathrm{Ca}$ in the limestone 
$\left(\mathrm{CaCO}_{3}\right)$ and $\mathrm{Ca}^{2+}$ and $\mathrm{CO}_{3}{ }^{2-}$ is released to the bulk solution. $\mathrm{Ca}^{2+}$ and $\mathrm{CO}_{3}{ }^{2-}$ ions released from the surface of the mineral must be transported away into the bulk of the solution by molecular diffusion. On the other hand, $\mathrm{CO}_{2}, \mathrm{H}_{2} \mathrm{CO}_{3}$, and $\mathrm{H}+$ must migrate from the bulk to the mineral's surface. Thus one molecule of $\mathrm{CO}_{2}$ is consumed to dissolve one $\mathrm{CaCO}_{3}$ unit (Figure 2).

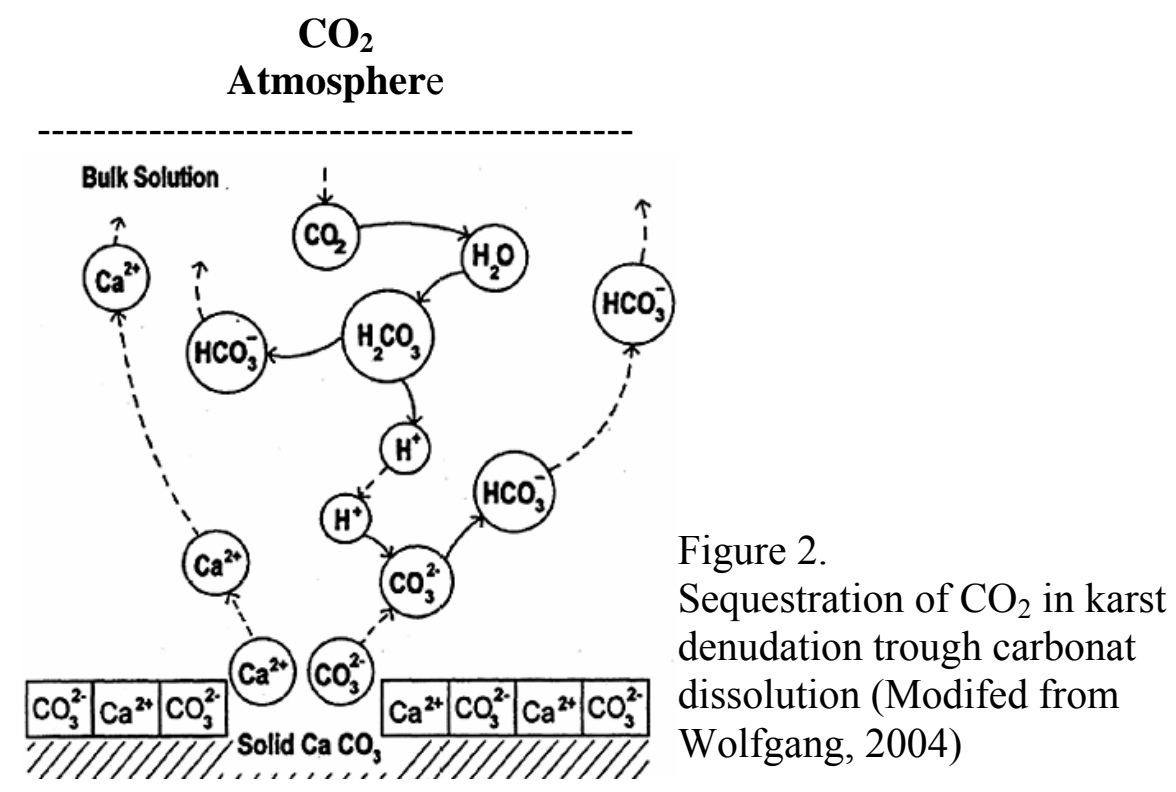

Carbonate rock dissolution have assumed that half of the dissolved inorganic carbon leaving a given catchment comes from the mineral and half from the atmosphere. Hence $120 \mathrm{~kg}$ carbon is uptakes from atmosphere during the removal of $1000 \mathrm{~kg}$ carbon through karst denudation.

\section{Denudation and carbon sequestration in Gunung Sewu Karst}

The calculation of karst denudation documented in this paper is based on Corbel (1956) formula (Formula 1).

$$
\mathrm{V}=\frac{4 \mathrm{ET}}{100}
$$

Where

$\mathrm{V}:$ Denudation rate by dissolution $\left(\mathrm{m}^{3} /\right.$ year $\left./ \mathrm{km}^{2}\right)$

E : Run off (Precipitation - Evaporation) in decimeter (dm)

$\mathrm{T}: \mathrm{CaCO}_{3}$ concentration in water discharged by karst springs $(\mathrm{mg} / \mathrm{l})$

The average precipitation in Gunung Sewu Karst is $\mathbf{2 . 0 5 1} \mathbf{~ m m} / \mathbf{y e a r}$. This figure was analyzed from 32 rain gauge stations recorded from 1945 to 2002 period. The averaged precipitation was calculated through isohyets method by using Arc-GIS software. On the other hand, evapotranspiration was estimated by Throunthwaite (1955) method. The annual potential evapotranspiration (PET) of Gunung Sewu Karst is $\mathbf{1 . 3 6 2 , 9 1 ~} \mathrm{mm}$. Temperature used for PET calculation was based on Wonosari weather 
station. Thus the annual runoff discharging from Gunung Sewu Karst is $\mathbf{6 8 8} \mathrm{mm}$. This figure is resulted from simply subtracting precipitation by evapotranspiration.

The carbonate concentration used in this paper is based on measurement in 22 springs conducted by Wijayanti (2002) Rini (2003). The carbonate concentration in water discharging by karst Springs in Gunung Sewu is summarized in Table 2. The concentration is bulk concentration without considering carbon source or sink that may take places within the Gunung Sewu Karst area. As it was described earlier that dissolution processes in karst areas is absorbed $\mathrm{CO}_{2}$ from atmosphere and soils respirated by biological decomposition. Inferring from Table 2, average $\mathrm{CaCO}_{3}$ removed from Gunung Sewu Karst is $\mathbf{1 8 5} \mathbf{~ m g / l}$.

Table 2. Dissolved $\mathrm{CaCO}_{3}$ discharging from karst Springs in Gunung Sewu Karst

\begin{tabular}{|c|c|c|c|c|c|}
\hline No & Mata Air & $\mathrm{CaCO}_{3}(\mathrm{mg} / \mathrm{l})$ & No & Mata Air & $\mathrm{CaCO}_{3}(\mathrm{mg} / \mathrm{l})$ \\
\hline 1 & Sumber Praci & 135 & 12 & Sumber Ponjong & 249 \\
\hline 2 & Sumber Beton & 176 & 13 & Sumber Nggremeng & 156 \\
\hline 3 & Sumber Waru & 210 & 14 & Sumber Beton & 200 \\
\hline 4 & Sumber Nangari & 158 & 15 & Sember Kenteng & 231 \\
\hline 5 & Sumber Sambiroto & 95 & 16 & Sumber Bendungan & 173 \\
\hline 6 & Sumber Weru & 327 & 17 & Sumber Selonjono & 231 \\
\hline 7 & Sumber Beji & 93 & 18 & Sumber Petoyan & 206 \\
\hline 8 & Sumber Teleng & 203 & 19 & Sumber Banyumudal & 234 \\
\hline 9 & Sumber Pule & 145 & 20 & Sumber Kalitangis & 220 \\
\hline 10 & Sumber Kali Suci & 93 & 21 & Sumber Mbeji & 218 \\
\hline 11 & Sumber Bendungan & 83 & 22 & Sumber Kalicacahan & 240 \\
\hline
\end{tabular}

Summarized from Wijayanti (2002) and Rini (2003)

Putting the runoff and average calcium carbonate concentration in Formula 1, the denudation rate of Gunung Sewu Karst is estimated to be $\mathbf{5 0 , 9 1} \mathrm{m}^{3} / \mathrm{km}^{2} /$ year. For the whole area of Gunung Sewu $\left(1300 \mathrm{~km}^{2}\right)$, this number is equivalent to $\mathbf{1 6 5 . 4 6 4}$ ton $\mathrm{CaCO}_{3}$ /year. This number is also carbon dioxide uptake from denudation process. Comparing with denudation rate in Tatrac-East Alp (60), Batu Cave-Malasya $(48,5)$, Carpathes-Ukraine(69,7), Lapoic-Norway (56-123), denudation rate estimation mentioned above seems reasonable. Hence, the estimate annual carbon dioxide sequestration in Gunung Sewu Karst through denudation processes is 72.804.16 ton. This number, one again, is merely from denudation process. Considering the considering carbon up takes by vegetation will inevitably gains much higher number. Different from other ecosystem where $\mathrm{CO}_{2}$ respiration through vegetation and organic decomposition is emitted, karst ecosystem otherwise uptakes all $\mathrm{CO}_{2}$ resulted from respiration. Only small portion of $\mathrm{CO}_{2}$ is emitted to the atmosphere trough precipitation of calcite or aragonite during the formation of speleothems. The most portion of the $\mathrm{CO}_{2}$ is brought to ocean in the form of bicarbonate ion. 


\section{Concluding Remarks}

General figure from karst denudation in Gunung Sewu karst obviously indicates that greater attention should be devoted to understand karst ecosystem in climate change mitigation. The important of karst denudation in term of climate changes lies on the ability of karst ecosystem in regulating atmospheric carbon through denudation processes. Karst denudation up takes $\mathrm{CO}_{2}$ both from atmosphere and soils. Considering carbon sequestration through biomass production, Gunung Sewu Karst ecosystem and other karst areas, that cover approximately 15 percent of Indonesian landmass, accordingly owes considerable role in climate change mitigation Therefore, attempts should be made to ascertain comprehensive carbon cycle mechanism in karst ecosystem including carbon cycle from biomass production in general or specifically from agricultural practices.

\section{References}

Balazs D, 1968, Karst Regions in Indonesia: Karszt-Es Barlangkutatas, Volume V. Budapest.

Corbel J., 1956, A new method for the study of limestone regions, Revue Canadienne de Geographie, 10, pp. 240-2.

Daoxian Y., 2002, The Carbon Cycle in Karst, IGCP report, Institute of Karst Geology, Guilin.

Dawson B. and Spannagle M., 2009, The Complete Guide to Complete Changes, Routledge, London.

Ford D. and Williams P.W., 2007, Karst Hydrogeology and Geomorphology, John Willey and Sons, Chicester.

Groves C, and Meiman J., 2001, Inorganic carbonflux and aquifer evolution in the south central Kentucky karst, U.S. Geological Survey Karst Interest Group Proceedings, Water-Resources Investigations Report, 01-4011, pp. 99-105

Gornitz V., 2008, Ensyclopedia of Paleoclimatology and Ancient Environment, Springer, the Netherlands.

Haryono E. 2005, Gunungsewu Karst Ecosystem Java-Indonesia, not published, Karst Research Group, Fac.of Geography, Yogyakarta.

Haryono E., Day M., 2004, Landform differentiation within the Gunung Kidul Kegelkarst, Java, Indonesia. Journal of Cave and Karst Studies, v. 66, no. 2, pp. 62-69.

Liu, Z. \& Zhao J., 2000, Contribution of carbonate rock weathering to the atmospheric $\mathrm{CO}_{2}$ sink. Environmental Geology. 39, pp. 1053-1058.

Mackenzie F.T., Lerman A., and Andersson A.J. 2004, Past and present of sediment and carbon biogeochemical cycling models, Biogeosciences, 1, pp. 11-32.

Palmer A.N, 2007, Cave Geology, Cave Books, Dayton, Ohio.

Parry M.L., Canziani O.F., Palutikof J.P. and Co-authors 2007: Technical Summary. Climate Change 2007: Parry, O.F. Canziani, J.P. Palutikof, P.J. van der Linden 
and C.E. Hanson, M.L. (Eds.), Impacts, Adaptation and Vulnerability. Contribution of Working Group II to the Fourth Assessment Report of the Intergovernmental Panel on Climate Change, Cambridge University Press, Cambridge, UK, pp. 23-78.

Rahardjo W, Sukandarrumidi, Rosidi H.M.D, 1995, Geological Map of The Yogyakarta Sheet, Java, Geological Research an Development Centre, Bandung.

Rini D.K., 2003, Karakteristik mataair karst di Kabupaten Wonogiri, Skripsi, Fakultas Geografi UGM, Yogyakarta.

Surono, BT, Sudarno I and Wiryosujono S, 1992, Geology of the Surakarta-Giritontro Quadrangles, Java. Geological Research and Development Center, Bandung.

Tornthwaite C.W., 1955, The water balance, Climatology, 8, pp 1-104.

van Bemmelen RW, 1970, The Geology of Indonesia, Volume 1A, General Geology: The Hague, Martinus Nijhoff.

Waltham AC, Smart PL, Friederich, H, Eavis, A.J \& Atkinson TC, 1983, The caves of Gunung Sewu, Java:, Cave Science, 10(2), pp. 55-96.

White, W.B., 1988, Geomorphology and Hydrology of Karst Terrains, New York: Oxford University Press, London.

Wijayanti P., 2002, Karakteristik hidrologi mataair karst di Kecamatan Ponjong-Kab. Gunung Kidul, Sekripsi, Fak. Geogrfi, Yogyakarta.

Wolfgang, D., 2004, Carbonate Dissolution, in Gunn, J. (eds), Encyclopedia of Caves and Karst Science, Taylor \& Francis Books, Inc., London.

\section{Indonesian Karst Region}

A

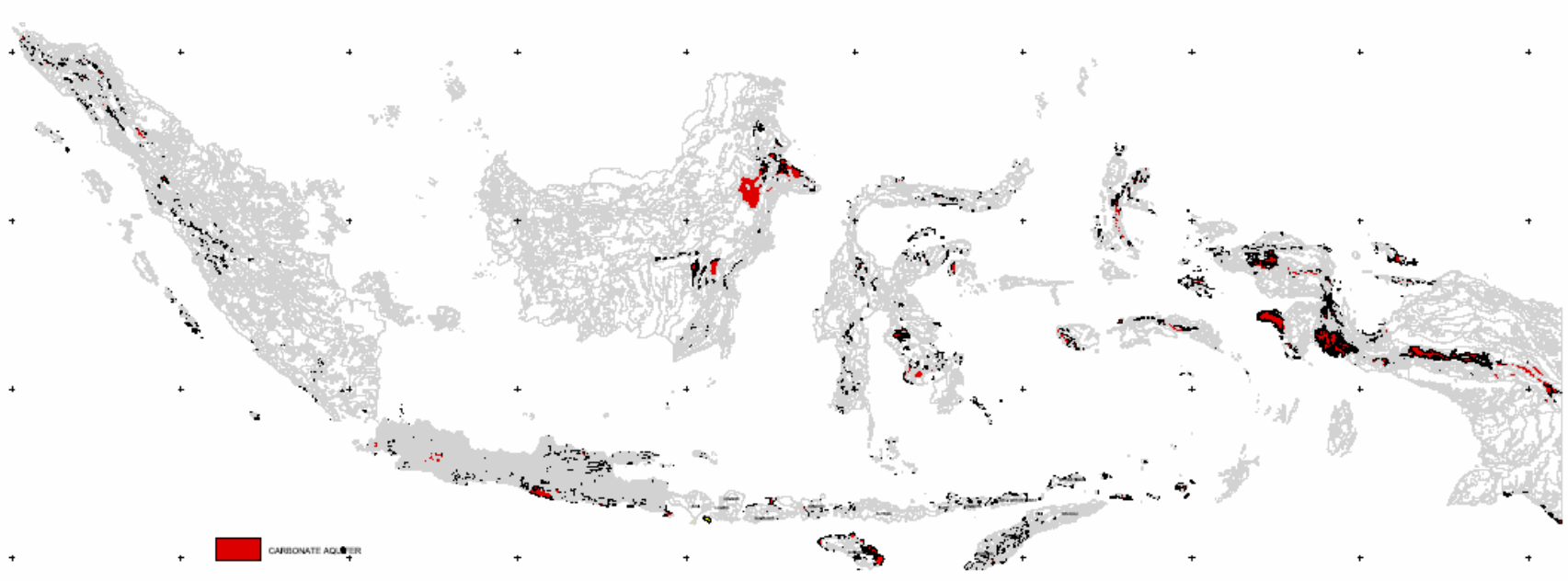

